\title{
The Prevalence of HBsAg, Anti HCV and Anti HIV Before Upper Gastrointestinal Endoscopy
}

\author{
Üst Gastrointestinal Endoskopi Ișlemi Öncesi HBsAg, Anti HCV ve Anti HIV Prevalansları
}

\author{
Sami CIFCI1, Murat BIYIK1, Mehmet ASIL1, Serhat SAYIN2, Hüseyin ATASEVEN1, Ali DEMIR1 \\ ${ }^{1}$ Konya Meram Necmettin Erbakan Üniversity Faculty of Medicine, Department of Gastroenterology, Konya, Turkey \\ 2Konya Meram Necmettin Erbakan Üniversity Faculty of Medicine, Department of Internal Medicine, Konya, Turkey
}

\begin{abstract}
Objective: This study was conducted to determine the preprocedure prevalence of hepatitis $B$, hepatitis $C$ and HIV in patients with dyspeptic complaints to whom an upper gastrointestinal endoscopy was performed and also to question the necessity of routine serologic testing.

Materials and Methods: Medical records of 242 adult patients who applied to Gastroenterology clinic of Necmettin Erbakan University Meram Faculty of Medicine with dyspeptic complaints during 2012 and to whom an upper gastrointestinal endoscopy was performed were analyzed retrospectively for preprocedure hepatitis $B$, hepatitis $C$ and HIV serologies.

Results: A total of 242 patients were taken into the study. 120 of them (49\%) were males and 122 of them (51\%) were females. Preprocedure prevalence of $\mathrm{HBs} \mathrm{Ag}$ and anti HCV was $2.9 \%$ and $0.4 \%$ respectively. Anti HIV was detected to be positive in none of the patients. In total $3.3 \%$ of patients were positive hepatitis serology. Conclusion: The preprocedure prevalence of hepatitis $B$ and $C$ in our patients was consistent with the prevalences reported for general population in previous studies. Taken into account that post procedure transmission of hepatitis $B$ and $C$ is rare, routine serologic testing is not necessary as far as disinfection rules are obeyed strictly in endoscopy clinics. (Viral Hepatitis Journal 2014; 20(2): 78-80)

Key words: Hepatitis B, hepatitis C, gastroscopy
\end{abstract}

ÖZET

Amaç: Bu çalışma dispeptik yakınmalar ile başvuran ve üst gastrointestinal endoskopi incelemesi önerilen hastalarda yapıldı. Çalışmanın amacı endoskopi işlemi öncesi hastalarda hepatit serolojisi ve Anti HIV serolojisini taramak ve prevalansını değerlendirmek, bunun sonucunda işlem öncesinde rutin seroloji isteminin gerekliliğini tartışmaktır.

Gereç ve Yöntemler: Çalışma 2012 ylında Konya Necmettin Erbakan Üniversitesi Meram Tıp Fakültesi Gastroenteroloji polikliniğine başvuran ve işlem öncesi hepatit ve HIV serolojisi bakılan toplam 242 hastayı kapsamaktadır.

Bulgular: Çalışmaya alınan toplam 242 hastanın; 120'si erkek (\%49), 122'si kadın (\%50) idi. Seropozitiflik oranları HBsAg \%2,9, Anti HCV \%0,4 iken Anti HIV pozitifliğine rastlanmadı. Toplamda hastaların $\% 3,3$ de hepatit serolojisi pozitif tespit edildi.

Sonuç: Hastanemizde endoskopi işlemi öncesi bakılan hepatit serolojisi oranlarının toplum prevalansına yakın değerlerde çıktığı görülmüştür, endoskopik işlemler sonrası hepatit bulaşının son derece nadir olduğu da göz önüne alınırsa endoskopi ünitelerinde yeterli dezenfeksiyon uygulamalarına riayet edilmesi takdirinde rutin serolojik testlerin gereksiz olduğu kanısına ulaşılmaktadır. (Viral Hepatit Dergisi 2014; 20(2): 78-80)

Anahtar Kelimeler: Hepatit B, hepatit C, gastroskopi

\section{Introduction}

With widespread use of endoscopic gastrointestinal procedures, contagious spread of infectious agents became a major concern and national and international guidelines were published. There is still debate weather current disinfections methods are adequate to prevent endoscopic transmission of hepatitis $B$ and $C$ viruses and weather routine preprocedure testing for hepatitis $B$ and $C$ serologies is advisable or not.

Hepatitis B infection is still a major health problem. It is estimated that there are 3 million people infected with hepatitis $B$ virus in Turkey and 450 million worldwide. Hepatitis B and C infections cause important morbidity and mortality via acute infection, chronic infection, cirrhosis and hepatocellular cancer (1).

The reported prevalence of hepatitis $C$ changes from $0.1 \%$ to $5 \%$ in different countries and the global prevalence reported by World Health Organization is $3 \%$ (2). The prevalence in Turkey ranges from $1 \%$ to $2.4 \%$ in different studies. Hepatitis C prevalence widely changes in different patient populations from $0.5 \%$ to $51.6 \%$ with highest prevalence among hemodialysis patients $(3,4)$.

In a study conducted in Konya, Turkey, 17071 blood donors between 2003-2009 were retrospectively analyzed and 
seropositivity for $\mathrm{HBs}$ antigen and anti $\mathrm{HCV}$ were found to be $1.53 \%$ and $0.5 \%$ respectively (5).

Hepatitis B and C transmissions occur via direct contact with, blood or body secretions of infected people, vertical transmission or via sexual contact (6).

Endoscopic devices can be classified as semicritical items in terms of disease transmission risk. Semicritical items contact mucous membranes or nonintact skin and so called "high level disinfection" is accepted to be convenient for appropriate disinfection. High level disinfection kills the vegetative form of pathogen bacteria, fungi and protozoa and inactivate viruses, a small number of bacterial spores may persist (7). The most widely used high level disinfectants are gluteraldehyde derivatives, hydrogen peroxide, paracetic acid and sodium hypochlorite (8).

The purpose of this study was to evaluate the preprocedure prevalence of hepatitis $B$, hepatitis $C$ and HIV in patients with dyspeptic complaints to whom an upper gastrointestinal endoscopy was performed and also to question the necessity of routine serologic testing.

\section{Materials and Methods}

242 patients with dyspeptic complaints who applied to Gastroenterology clinic of Konya Necmettin Erbakan University Faculty of Medicine in 2012 and to whom an upper gastrointestinal endoscopy were performed were taken into the study. Preprocedure HBsAg, anti HCV and anti HIV were obtained. Serologic tests were performed in the microbiology laboratory of our hospital with ELISA method using Architect brand kits.

\section{Results}

Two hundred forty-two patients were taken into the study. One hundred and twenty patients were males (49.6\%) and 122 were females (50.4\%). The mean age of the patients were 51 (range 18-81 years). Seven of the patients $(2.9 \%)$ were found to be seropositive for HBs antigen and 1 patient $(0.4 \%)$ was anti $\mathrm{HCV}$ positive (Figure 1). None of the patients was HIV positive.

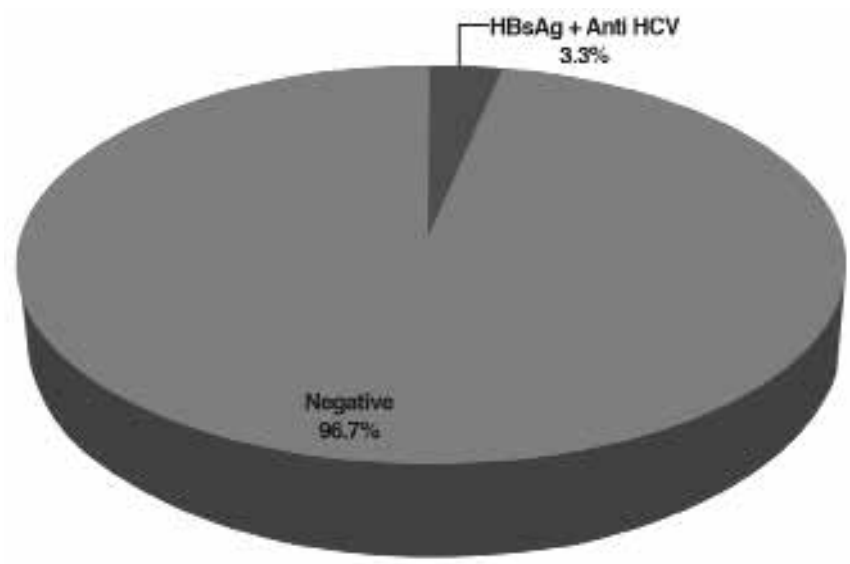

Figure 1. Total number of HBsAg positive and anti HCV positive patients.

\section{Discussion}

Hepatitis B and C constitute important health problems even though hepatitis prevalence decline due to improved global socioeconomic conditions and worldwide vaccination programmes. The prevalences in our country are also decreasing among healthy blood donors (9). Emekdas et al. investigated HBs Ag seroprevalence among volunteer blood donors of Turkish Red Crescent Association. The results of the study showed that HBs antigen prevalence was $4.92 \%$ in 1989 which rose to $5.23 \%$ in 1991. The prevalence showed a significant decline and was found to be $2.1 \%$ in 2004 (10). The prevalence in Konya was investigated by Guzelant et al. and was found to be $1.48 \%$ between 2007 and 2008, which was lower than the previous years (11).

Hepatitis C prevalence is lower than hepatitis B worldwide and also in our country. Routine testing for anti $\mathrm{HCV}$ is obligatory since 1996 in Turkey among blood donors (12). Hepatitis C prevalence was found to be $0.54 \%$ among 1.076 .495 blood donors between 2000 to 2006 (9). In a study conducted in 2010 anti HCV prevalence was $0.95 \%$ among 5471 healthy people. The same study showed that HBs Ag prevalence was $4 \%$ and anti HBs prevalence was $32 \%$ respectively. The study also found $\mathrm{HBs} \mathrm{Ag}$ prevalence in Konya region as $2.1 \%$ and that both $\mathrm{HBs} \mathrm{Ag}$ and anti $\mathrm{HCV}$ prevalences were lower among young people (13).

It is usually very difficult to document hepatitis B transmission during endoscopic procedures because the incubation period can be quite long and the acute infection can be asymptomatic. Hoofnagle et al. conducted a prospective study with $186 \mathrm{HBs}$ Ag positive patients. The results of this study showed that no transmission occurred during endoscopic procedures as long as the standard disinfection procedures were performed. The authors concluded that hepatitis transmission during endoscopic procedures was rare and routine preprocedure testing for hepatitis B serology was unnecessary (14).

Villa et al. reported that significant Hepatitis B transmission didn't occur during endoscopy (15). Also in another study conducted by Mele et al., endoscopic hepatitis B transmission risk was not found to be significant (16). In a study investigating HIV transmission during endoscopy, all channels of 5 endoscopes were contaminated with serums containing high HIV titers. After standard disinfection procedures it was seen that 4 of the endoscopes were free of HIV virus. There was also a $99.99 \%$ decrease of HIV in the 5th endoscope which was also eliminated after 2 minutes of disinfection with gluteraldehyde (17).

It was shown that 10 minutes of disinfection is enough for endoscopic devices contaminated with hepatitis B, C or HIV viruses (18). In a study conducted in our country 300 patients were observed for hepatitis B and C prevalences after upper gastrointestinal endoscopy and no significant difference was observed between study and control groups (19).

Our study showed HBs Ag prevalence of $2.9 \%$ and anti HCV prevalence $0.4 \%$, both of which were consistent with previous studies conducted in our region. These prevalences in our region are not so high. Previous studies showed that the risk of hepatitis $\mathrm{B}$ and $\mathrm{C}$ transmission during endoscopy is very low. There are still many centers in our country routinely performing hepatitis $B$ and C serologic tests prior to endoscopic procedures. We believe that as long as national and international disinfection guidelines are 
obeyed, the risk of endoscopic transmission of hepatitis B and $C$ is very low. Routine serologic testing for hepatitis $B$ and $C$ is unnecessary and it increases procedural costs.

\section{Conflict of interest: None declared.}

\section{References}

1. Dilek I, Demir C, Bay A, Akdeniz H, Oner AF Seropositivity rates of HBsAg, anti-HCV, anti-HIV and VDRL blood donors in Eastern Turkey. Turk J Hematol. 2007; 24(1): 4-7.

2. No authors listed. Hepatitis C: global prevalence. Wkly Epidemio Rec. 1997; 72(46): 341-4.

3. Ökten A. Hepatit $C$ virüsü enfeksiyonu-genel bakış. Tekeli $E_{\text {, }}$ Balık I (editörler). Viral Hepatit 2003. Ankara: Viral Hepatitle Savaşım Derneği; 2003; 184-5.

4. Dinçer D. Hepatit C Epidemiyolojisi ve Patogenezi. Türkiye Klinikleri J Gastroenterohepatol-Special Topics. 2010; 3(1): 77-80.

5. Turan H, Şerefhanoğlu K, Kanat G, Arslan H. Konya Ilinde Kan Donörlerinde HBsAg ve Anti-HCV Seroprevalansı ve Yaş ve Cinsiyetle Ilişkisi. Klimik Dergisi. 2011; 24(1): 36-9.

6. Thomas DL, Ray SC, Lemon SM. Hepatitis C. In: Mandell GL, Bennett JE, Dolin R, eds. Mandell, Douglas, and Bennett's Principles and Practice of Infectious Diseases. 6th ed. New York: Churchill Livingstone; 2005; p. 1950-81.

7. Palabıyıkoğlu I. Endoskopi ile ilişkili infeksiyonlar ve Endoskopların Dekontaminasyonu - II. Hastane infeksiyonları Dergisi. 1998; 2: 34-41.

8. Dezenfeksiyon, Antisepsi, Sterilizasyon (DAS) Derneği. Sterilizasyon ve Dezenfeksiyon Rehberi. 2011; 20-7.

9. Mıstık R. Türkiye'de viral hepatit epidemiyolojisi yayınların irdelenmesi. Tabak F, Balık I, Tekeli E (editörler.) Viral Hepatit 1. baskı. İstanbul: Viral Hepatitle Savaşım Derneği; 2007; 10-50.
10. Emekdaș G, Cavuşlu S, Öncül O, Artuk Ç, Aksoy A. Trends in hepatitis $B$ and hepatitis $C$ virus among blood donors over 16 years in Turkey. Eur J Epidemiol. 2006; 21(4): 299-305.

11. Güzelant A, Kurtoğlu MG, Kaya M, Keşli R, Baysal B. Kan vericilerinde ve bir ağız-diş sağlığı merkezi çalışanlarında hepatit $B$, hepatit $C$ ve HIV seroprevalansı ile vericilerde risk faktörlerinin araştırılması. Infeks Dergisi. 2008; 22(4); 189-95.

12. Kocak N, Hepgul S, Ozbayburtlu S, Altunay H, Ozsoy MF, Kosan $\mathrm{E}$, et al. Trends in major transfusion-transmissible infections among blood donors over 17 years in Istanbul, Turkey. J Int Med Res. 2004; 32(6): 671-5.

13. Nurdan Tozun, Osman C. Ozdogan, Yilmaz Cakaloglu, Ramazan Idilman, Zeki Karasu, Ulus S. Akarca, et al. A Nationwide Prevalence Study and Risk Factors for Hepatitis A, B, C and D Infectıons in Turkey. Hepatology. 2010; 52(Suppl 1): 697.

14. Hoofnagle JH, Blake J, Buskell-Bales Z, Seeff LB. Lack of transmission of type $B$ hepatitis by fiberoptic upper endoscopy. J Clin Gastroenterol 1980; 2(1): 65-9.

15. Villa E, Pasquinelli C, Rigo G, Ferrari A, Perini M, Ferretti I, et al. Gastrointestinal endoscopy and HBV infection: no evidence for a causal relationship. A prospective controlled study. Gastrointest Endosc. 1984; 30(1): 15-7.

16. Mele A, Spada E, Sagliocca L, Ragni P, Tosti ME, Gallo G, et al. Risk of parenterally transmitted hepatitis following exposure to surgery or other invasive procedures: results from the hepatitis surveillance system in Italy. J Hepatol. 2001; 35(2): 284-9.

17. Hanson PJ, Gor D, Jeffries DJ, Collins JV. Elimination of high titre HIV from fiberoptic endoscopes. Gut 1990; 31(6): 657-9.

18. Martin MA, Reichelderfer M. APIC Guideline for infection prevention and control in flexible endoscopy. In: Olmsted RN (ed). APIC infection control and applied principles and epidemiology practice. St.Louis: Mosby; 1996; p. 1-18.

19. N. Yenice, G. Gençdal, N. Aksoy, S. Kalyon, O. Akın. Üst gastrointestinal sistem endoskopisi yapılmış hastalarda Hepatit $B$ ve Hepatit C sıklığı. Akademik Gastroenteroloji Dergisi. 2009; 8 (2): $82-7$. 